IRA-International Journal of Management \&

Social Sciences

ISSN 2455-2267; Vol.17, Issue 03 (Q.3 2021)

Pg. no. 89-97.

IRA Academico Research

\title{
Peace and Security Sustainability through Hostel Provision in Nigerian Universities: Lessons from Malaysia
}

\author{
Isaac Terungwa Terwase ${ }^{1 \#(D)}$, Ismail Bello² (i), Jude Onyekachi Onwuanibe ${ }^{1}$ (i) \& \\ Mohammed Abubakar Sambo ${ }^{1}$ (iD \\ ${ }^{1}$ Department of Political Science, Federal University of Kashere, Nigeria. \\ ${ }^{2}$ Department of International Relations and Diplomacy, Baze University, Abuja, Nigeria
}

\# corresponding author

Type of Work: Peer Reviewed.

DOl: https://dx.doi.org/10.21013/jmss.v17.n3.p2

How to cite this paper:

Terwase, I.T., Bello, I., Onwuanibe, J.O., Sambo, M.A. (2021). Peace and Security Sustainability through Hostel Provision in Nigerian Universities: Lessons from Malaysia. IRA-International Journal of Management \& Social Sciences (ISSN 2455-2267), 17(3), 89-97. DOI:

https://dx.doi.org/10.21013/jmss.v17.n3.p2

(C) IRA Academico Research.

(cc) EY-NC This work is licensed under a Creative Commons Attribution-NonCommercial 4.0 International License subject to a proper citation to the publication source of the work.

Disclaimer: The scholarly papers as reviewed and published by IRA Academico Research are the views and opinions of their respective authors and are not the views or opinions of IRA Academico Research. IRA Academico Research disclaims any harm or loss caused due to the published content to any party.

IRA Academico Research is an institutional publisher member of Publishers International Linking Association Inc. (PILA-CrossRef), USA. IRA Academico Research is an institutional signatory to the Budapest Open Access Initiative. Hungary advocating the open access of scientific and scholarly knowledge. IRA Academico Research is a registered content provider under Open Access Initiative Protocol for Metadata Harvesting (OAI-PMH).

The journal is indexed \& included in WorldCat Discovery Service (USA), CrossRef Metadata Search (USA), WorldCat (USA), OCLC (USA), Open J-Gate (India), EZB (Germany) Scilit (Switzerland), Airiti (China), Bielefeld Academic Search Engine (BASE) of Bielefeld University, Germany, PKP Index of Simon Fraser University, Canada.

Isaac Terungwa Terwase (D/0000-0002-9231-8707

Ismail Bello (i)/0000-0002-6484-9906

Jude Onyekachi Onwuanibe (D)/0000-0002-4018-185X

Mohammed Abubakar Sambo (iD)/0000-0003-4146-6141 


\section{ABSTRACT}

This research paper focused on the provision of students' accommodation in the Nigerian universities through public-private partnership drawing lessons from the Universiti Utara Malaysia. Hostel accommodation is a form of providing the students with an enabling environment where they can stay as a place of residence, will feel secured and comfortable to learn in a peaceful environment. The objective of this paper is to learn from the Malaysian environment with a focus on the Universiti Utara Malaysia. The research work made use of the qualitative method through the conduct of interviews and other sources such as journals and online publications. Findings from the research reveal that the Universiti Utara Malaysia provides hostel accommodation which is more than enough to serve the university's capacity of 30,000 students' population on campus through the public-private partnership scheme. The research also found that multinational companies like PETRONAS Oil Company, Proton automobile company, Malaysia Airline, and Maybank among other companies built hostel accommodation for the students. The Malaysian Government on the other hand through a public-private partnership provided infrastructural facilities such as constant electricity and water supply for the purpose of a conducive environment for learning. The work, therefore, recommends that the Nigerian Government can partner with the Malaysian Government through resolving the big problem of electricity supply in the country and on the Universities as well. The paper also recommends that the Nigerian Government should regulate the private companies in order to engage them in partnership development through the provision of adequate hostel accommodations for the students. This would enable peace and security sustainability on the campuses of the Nigerian universities with lessons from the Universiti Utara Malaysia.

Keywords: Peace and Security Sustainability, Nigerian Universities, Malaysia, Hostel Accommodations, and Private Companies.

\section{Introduction}

The work of Bashir, Sarki, \& Samidi (2012) connotes that, the provision of hostel accommodation on university campuses enables the students to make use of their time and the available facilities in sustaining their studies within the universities. The whole essence of hostel accommodation is to provide an enabling environment for the students to study peacefully and as long as the environment is secured. Crankshaw, \& Parnell (1996) views that a residential environment is essential to human sustenance since it can provide a place where people could reside.

Research has been conducted by other scholars such as Khozaei, Ayub, Hassan \& Khozaei (2010) on students' satisfaction with university hostels using the Universiti Sains Malaysia as a case study. The major factor of the study was based on students' satisfaction which is the component of peace and security sustainability on university campuses. The security of the students on university campuses is very crucial and thus, it promotes a peaceful environment as long as the students remain satisfied with the number of hostel accommodations provided to them.

In this study, the paper focused on lessons from Malaysia's educational system using the Universiti Utara Malaysia (UUM) as a case study where numerous hostel accommodations are provided within the campus and adequate facilities such as constant electricity supply, water supply, reading rooms and reading facilities are equally provided. The idea is to learn from UUM considering the fact that Nigerian Public Universities needs to borrow a leaf from UUM on how to partner with the private companies in Nigeria such as MTN telecommunication, Shell Petroleum, Julius Berger Construction Company, and First Bank PLC, representing the telecommunication industries, petroleum industries, construction industries and banking sector respectively.

Sawyerr \& Yusof, (2013) argues that students' dissatisfaction with the hostel accommodation on campus could affect their studies. Their work measured dissatisfaction based on the common room, bedroom, bathroom and other facilities needed by the students within their hostels. The study made use of Kaduna Polytechnic in Nigeria which is also a public institution of higher learning. The work of Adewunmi, Omirin, Famuyiwa \& Farinloye (2011) agree that students could decide to stay far away from the university location due to the availability of cheap accommodation in such an environment. However, the work notes that the cost of transporting to and fro the university campus could also affect the performance of the students involved.

Khozaei, Ayub, Hassan, \& Khozaei (2010) revealed in their work how a student concurred his staying on campus could help him get up early in the morning and walk to the lecture hall while staying off-campus may affect the performance in relation to distance. Nimako \& Bondinuba (2013) observed that there is a need for construction and management of students' hostel accommodation on university campuses. This is in view of the fact that such 
provision and maintenance could boost the peace and security sustainability of the university community. This research work would, therefore, move to the main objectives of the study with a further discussion of the paper.

\section{Research Objectives}

The main objectives of this study include:

i) To draw lessons from the Malaysian Educational System through her adequate provision of students' hostel accommodation using the public-private partnership model.

ii) To promote a public-private partnership initiative in Nigeria's public universities on the provision of hostel accommodation.

iii) To promote measures on peace and security sustainability in Nigeria's public universities through the process of providing adequate facilities and maintenance of the hostel accommodation.

\section{Significance of the Study}

The paper has presented a useful guide on how the Nigerian Government can draw her lessons from the Malaysian educational system in relation to a partnership with the private sector on the provision of adequate hostel accommodation to the public universities in Nigeria. The research work has demonstrated how Universiti Utara Malaysia as a public institution partnered with the private sector on providing adequate hostel accommodation to the students on campus.

This research work, therefore, provides public policymakers sufficient knowledge on public-private partnership in relation to building adequate accommodation and bridging the gap on the campuses due to the lack of sufficient residential apartments for the students. It has bridged the gap and provided new knowledge to those in the field of estate management, building and construction industries on the version of Build, Operate and Transfer (B.O.T). Such gaps exist in the Nigerian universities across the federation which could be filled through the publicprivate partnership for the purpose of promoting peace and security sustainability on the campuses.

The work is also relevant to the students of Corporate Governance and CorporateSocial Responsibility as well as those in the field of Peace and Security Sustainability. The research provides new knowledge on how other countries can learn from the Malaysian Educational System with a specific example from the Universiti Utara Malaysia where the public-private partnership has yielded a tremendous contribution to the provision of hostel accommodation on the University campus.

\section{Conceptual Framework}

\section{- Public-Private Partnership}

The quest for infrastructural development in the universities for the purpose of achieving educational advancement has led to the need for public-private partnerships. The concept of public-private partnership in this research work, therefore, emphasized the government's partnership with the private sector on providing the needed infrastructure on the University campus. In this regard, the work of Zhang (2005) agrees that the concept of public-private partnership has become a global practice where the goal is aimed at solving infrastructural development problems as encountered.

Universiti Utara Malaysia through her public-private partnership arrangements thus, built and made available on the campus hostel accommodations where the students tend to benefit from the peaceful environment. Grimsey\& Lewis (2007) concurred that a new trend emerges as governments the world over, goes into partnership with the private sector in developing the infrastructural base. The private sector provides the financial base as well as the construction and management of the infrastructure before transferring it to the government.

Ke, Wang \&Chan (2010) opined that public-private partnership thus takes the effective risk and strategic management of the projects in order to obtain sufficient oriental goals. This means that the process of negotiating, carrying out and taking the risk involved in building and constructing the projects and maintaining such projects when they have completed to the stage of handing over to the University as the case may be. Kwak, Chin \&Ibbs (2009) connotes public-private partnership has become a major tool in addressing the need for infrastructural development which could be done effectively and achieving the desired goal towards the sustenance of adequate infrastructure provision. 
IRA-International Journal of Management \& Social Sciences

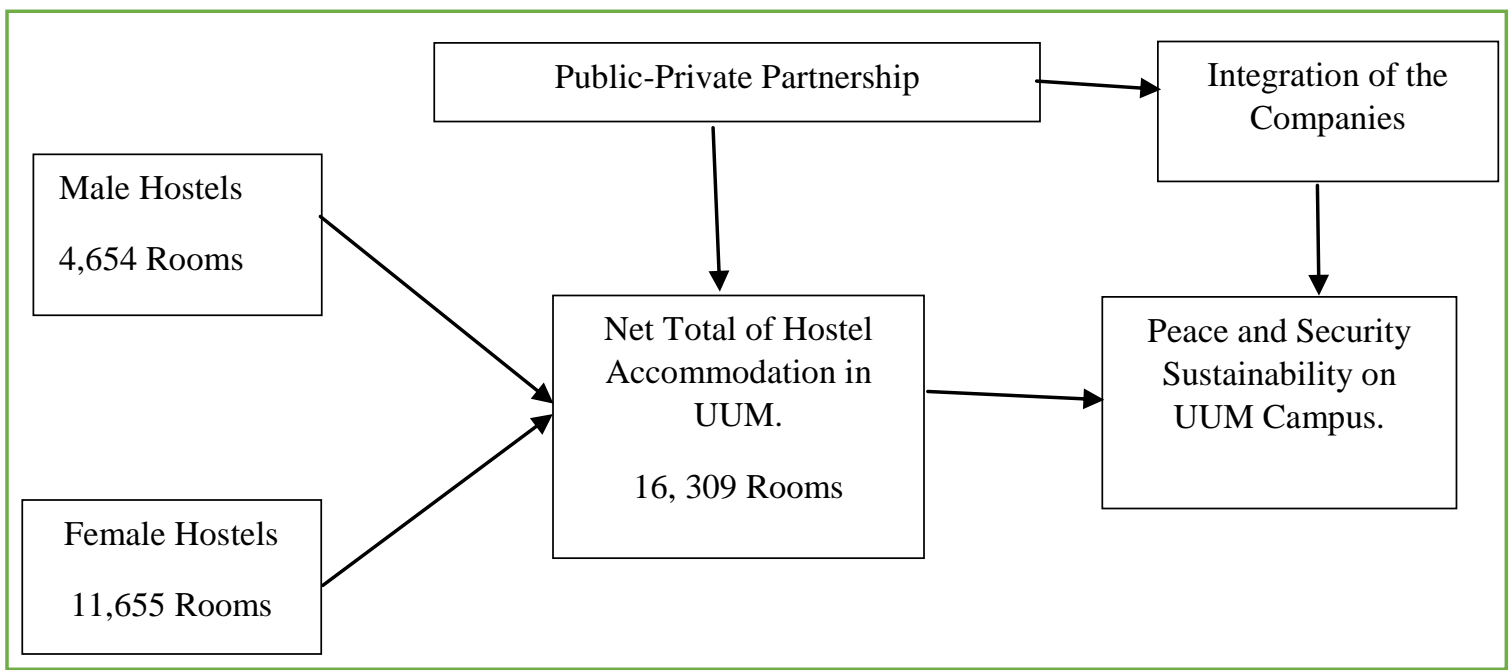

Figure 1. Conceptual Framework of Public-Private Partnership on the provision of Hostel accommodation at the Universiti Utara Malaysia.

\section{- Integration of Companies}

The strength of this research work is focused on the role of a public-private partnership in the integration of the companies on the UUM campus in relation to the building of the hostel accommodations for the students. These companies/industries/organizations include Bank Muamalat, Bank Rayat, BSN, EON, MAS, MISC, PETRONAS, PROTON, SIME DARBY, SME BANK, TM, TNB, TRADEWINDS and Yayasan Albukhary. Their role in partnering with the Federal Government of Malaysia through the UUM as a public university has sustained the peaceful and secured environment on the campus.

\section{Peace and Security Sustainability}

Peace and security as presented in the work of Terwase, Abdul-Talib \& Zengeni (2015) reveal that peace is the absence of crisis and violence which could have been as a result of political, social, cultural and economic motivated interest. However, in the context of this work, security refers to the protection of lives and property. Nigeria is seen as a large market for international business and this factor promotes the activities of both local and international companies/organizations to do business in Nigeria as Africa's largest economy (Terwase, Abdul-Talib \& Zengeni, 2014). Therefore, there is a need for companies from the banking industries, construction industries and telecommunication industries to go into partnership with the government in building hostel accommodations across the federal and states' universities in Nigeria.

\section{Methodology}

The research work made use of the qualitative method through the conduct of interviews and other sources such as journals and online publications. The work also collected data on the students' hostel accommodation to know the companies involved in the partnership with the school on building the hostel accommodation. The data was collected from the Students' Accommodation Center (SAC) of the Universiti Utara Malaysia for the purpose of this research.

\section{Data Analysis and Discussion}

Table 1 below presents a total of fourteen (14) companies involved in building students' hostel accommodation on the campus of UUM. It is revealed from Table 1 that, during the second semester of the 2016/2017 academic session, a total number of 4,654 rooms were provided for male students' accommodation while 3,491 rooms only were occupied and 1,163 rooms' remains unoccupied. 
Table 1

Data on Male Hostels, Universiti Utara Malaysia

\begin{tabular}{|c|c|c|c|c|}
\hline & & MALE H & & \\
\hline $\mathbf{S} / \mathbf{N}$ & Hostel Name & Capacity & Room Occupied & Empty Space \\
\hline 1 & Bank Muamalat & 0 & 0 & 0 \\
\hline 2 & Bank Rayat & 820 & 638 & 182 \\
\hline 3 & BSN & 0 & 0 & 0 \\
\hline 4 & EON & 263 & 234 & 29 \\
\hline 5 & MAS & 0 & 0 & 0 \\
\hline 6 & MISC & 243 & 224 & 19 \\
\hline 7 & PETRONAS & 236 & 202 & 34 \\
\hline 8 & PROTON & 412 & 254 & 158 \\
\hline 9 & SIME DARBY & 0 & 0 & 0 \\
\hline 10 & SME BANK & 837 & 515 & 322 \\
\hline 11 & TM & 496 & 402 & 94 \\
\hline 12 & TNB & 237 & 153 & 84 \\
\hline 13 & TRADEWINDS & 324 & 232 & 92 \\
\hline 14 & Yayasan Albukhary & 786 & 637 & 149 \\
\hline & Total & 4654 & 3491 & 1163 \\
\hline
\end{tabular}

Table 2

Data on Female Hostels, Universiti Utara Malaysia

\begin{tabular}{|lllll|}
\hline \multicolumn{5}{|c|}{ FEMALE HOSTEL } \\
\hline S/N & Hostel Name & Capacity & Room Occupied & Empty Rooms \\
\hline 1 & Bank Muamalat & 1541 & 1281 & 260 \\
\hline 2 & Bank Rayat & 1312 & 1014 & 298 \\
\hline 3 & BSN & 784 & 729 & 55 \\
\hline 4 & EON & 754 & 664 & 90 \\
\hline 5 & MAS & 983 & 854 & 129 \\
\hline 6 & MISC & 491 & 406 & 70 \\
\hline 7 & PETRONAS & 726 & 656 & 244 \\
\hline 8 & PROTON & 331 & 87 & 129 \\
\hline 9 & SIME DARBY & 1050 & 921 & 550 \\
\hline 10 & SME BANK & 1315 & 765 & \\
\hline & & & & \\
\hline
\end{tabular}


IRA-International Journal of Management \& Social Sciences

\begin{tabular}{|lllll|}
\hline 11 & TM & 494 & 428 & 66 \\
\hline 12 & TNB & 741 & 510 & 231 \\
\hline 13 & TRADEWINDS & 327 & 265 & 62 \\
\hline 14 & Yayasan Albukhary & 806 & 698 & 108 \\
\hline & Total & $\mathbf{1 1 6 5 5}$ & $\mathbf{9 2 7 8}$ & $\mathbf{2 3 7 7}$ \\
\hline
\end{tabular}

Table 2 has presents concrete information on the female students' hostel accommodation at the Universiti Utara Malaysia. The data presented is for the second semester 2016/2017 academic session bearing a total number of 11,655 rooms provided for the female students. The research revealed that only 9,278 rooms were occupied while 2,377 rooms were unoccupied by the female students.

This has shown how well prepared the Universiti Utara Malaysia planned for adequate provision of hostel accommodations for her students considering the fact that both male and female students in UUM have the opportunity to get a place of residence on campus. As such, there are lessons to be learned from the Malaysian Educational System in securing adequate accommodation for the student which in turn would promote peace and security sustainability on campus.

Table 3

Net Total of the Hostels, Universiti Utara Malaysia

\begin{tabular}{|lllll|}
\hline \multicolumn{5}{l}{ NET TOTAL } \\
\hline S/N & Hostel Name & Capacity & Room Occupied & Empty Rooms \\
\hline 1 & Bank Muamalat & 1541 & 1281 & 260 \\
\hline 2 & Bank Rayat & 2132 & 1652 & 480 \\
\hline 3 & BSN & 784 & 729 & 55 \\
\hline 4 & EON & 1017 & 898 & 119 \\
\hline 5 & MAS & 983 & 854 & 129 \\
\hline 6 & MISC & 734 & 630 & 104 \\
\hline 7 & PETRONAS & 962 & 858 & 104 \\
\hline 8 & PROTON & 743 & 341 & 402 \\
\hline 9 & SIME DARBY & 1050 & 921 & 129 \\
\hline 10 & SME BANK & 2152 & 1280 & 872 \\
\hline 11 & TM & 990 & 830 & 160 \\
\hline 12 & TNB & 978 & 663 & 315 \\
\hline 13 & TRADEWINDS & 651 & 497 & 154 \\
\hline 14 & Yayasan Albukhary & 1592 & 1335 & 257 \\
\hline & Total & $\mathbf{1 6 3 0 9}$ & $\mathbf{1 2 7 6 9}$ & $\mathbf{3 5 4 0}$ \\
\hline & & & & \\
\hline
\end{tabular}

Table 3, of this research work, revealed that the total capacity of the students' hostel accommodations understudy as listed are only 14 in number, considering the fact that other residential accommodations such as Maybank and Taman Universiti are not included in this research. The research, therefore, has clearly shown how a total number of 16,309 rooms were provided for the students' hostel accommodation on UUM campus. 
The findings from the study revealed that, out of the 16,309 rooms provided for both male and female students, only12, 769 rooms were occupied while 3,540 rooms remained unoccupied. The research has proved that the UUM as a public university in Malaysia went into partnership with the private companies in building the students' hostel accommodation on the campus which has also promoted peaceful and secured residence for the students. There are lessons that need to be impacted on the Nigerian Universities in providing adequate accommodations for the students. In view of this, Tondo, a student of the University of Agriculture, Makurdi, connotes that:

There are no sufficient hostel accommodations in the University of Agriculture, Makurdi, Nigeria. The ones there are in the South core where there are just two Upstairs building for the girls while there is another one called Zamfara hostel for boys in the North core, but even then they are very small and cannot accommodate many students. The rooms are quite small and sometimesaccommodate10, although as for now, there is a noticeable improvement as overcrowding has reduced ( $28^{\text {th }}$ of June, 2017).

More so, there are challenges to staying outside the University campus. Most of the issues that surround staying offcampus include insecurity and it also affects the academic performance of the students due to late coming to school as a result of traffic congestions. In this regard, Tondo again agrees that:

Some of the challenges are first, that of insecurity, it's like one is not a student of the University because one is off-campus, I was off-campus too, so I know what I faced. So, even though we were close to the University premises, it was no fault of ours as we didn't go on our own accord, it was because of insufficient accommodation that we had to fall on the option of staying offcampus. It is like the school administration does not care about us, they feel we are not their responsibility, so they cannot even help us. Another issue we experienced was that of insufficient water, the whole of the village where we stayed had only one borehole present and the villagers would struggle with students over water, eventually, some students can't even get water $\left(28^{\text {th }}\right.$ of June, 2017).

In another dimension, Iornenger, a student of Benue State University, Makurdi, Nigeria, also shared experiences on students' hostel accommodations that:

They do not have sufficient accommodation on the University campus. But the ones present are very few. There are challenges for those who stay outside the campus as I did, and I was not able to be as punctual as I was meant to be. Most times because of traffic, I would get to school late. In most cases, I could not participate in some of the activities on campus, like we had tutorial classes and because I wasn't staying on campus, I would get to know about it so late and I missed a lot. There were challenges of security too as some students who stayed off-campus were reported to have had issues such as theft, maybe after reading in school and going back, they had their phones stolen and also the places they lived were invaded time( $28^{\text {th }}$ of June, 2017).

The findings also show that there are lessons to be learned from Malaysia with a specific example from UUM. The Nigerian government should also go into partnership with the private sector in order to resolve such problems facing the students such as inadequate hostel accommodations which become a source of trauma for the students. As such, Tondo, further argues that:

In some other Universities, what they do to help the situation of students' accommodation on campus is to allow some persons to come and invest on the school premises by erecting buildings on the campus, afterwards there would be a kind of agreement between the school and the investors, that after building and getting what they want, they eventually hand over to the school administration and leave. In fact, I remember that there was a time where a particular body came to the school for that kind of offer but the school refused from what I gathered, this was during the former leadership of the university 
and they turned their offer down, I really do not understand why they refused. I do not know if they just want the students to suffer. This is because I remember during the orientation of my set, we were given questionnaires to answer questions on aspects of accommodation, but nothing ever came out of it $\left(28^{\text {th }}\right.$ of June, 2017).

On how to improve the situation of inadequate hostels for the students' accommodation on the university campuses, Iornenger, a student of Benue State University, Makurdi, opined that:

\begin{abstract}
More hostels should be built, even if they will not be freely given. I also think other individuals should be encouraged to build hostel accommodation on campus and give them out on rent to students, so the campus will be able to accommodate more students to reduce some of those issues (28 $8^{\text {th }}$ of June, 2017).
\end{abstract}

Terwase, Abdul-Talib, Zengeni \& Terwase (2015) opined that the suffering of the people could result in psychological trauma. In this case, students could also be traumatized due to lack of accommodation/residence for them in order to engage in their academic pursuits.

\title{
Conclusion/Implication
}

The issues surrounding insufficient students' hostel accommodation in Nigeria can be corrected with lessons from the Malaysian System of education using UUM as an example. Some of these issues include insecurity off-campus where some students reside, lack of adequate facilities such as water supply, electricity, internet facilities, as well as inadequate hostel accommodations on campus. Hence, the issues affect student performance in the universities as found during the interviews. The paper concludes that Nigerian public universities through the federal and states' government should study and adopt the Malaysian example.

\section{Recommendation}

The findings from this research draw the following recommendations:

- There is a need for a public-private partnership between the government and the private sector such as engaging the oil companies in Nigeria, telecommunication industries, banking sector and construction companies in building hostels on the public university campuses in Nigeria as studied in this research work.

- More funding should be provided by the government to enable the public universities in carrying out researches and providing the needed basic facilities to the universities.

- The appropriate mechanism should be put in place to address issues such as ineffective leadership on the part of the university administrators.

- Peace and security should be sustained in Nigerian universities in order to enable a peaceful environment for learning and achieving academic excellence.

Note: the following were interviewed for the purpose of this study.

Iornenger, D., a student of Benue State University, Makurdi, Nigeria, was interviewed on $28^{\text {th }}$ of June, 2017.

Tondo, M., a student of the University of Agriculture Makurdi, Nigeria, was interviewed on $28^{\text {th }}$ of June, 2017.

\section{References}

[1]. Adewunmi, Y., Omirin, M., Famuyiwa, F., \& Farinloye, O. (2011).Post-occupancy evaluation of postgraduate hostel facilities. Facilities, 29(3/4), 149-168.

[2]. Aluko, O. E. (2011). The assessment of housing situation among students in the University of Lagos. African Research Review, 5(3).

[3]. Bashir, S., Sarki, I. H., \& Samidi, J. (2012). Students' perception on the service quality of Malaysian universities' hostel accommodation. International Journal of Business and Social Science, 3(15).

[4]. Crankshaw, O., \& Parnell, S. (1996, June). Housing provision and the need for an urbanization policy in the new South Africa. In Urban Forum. Springer Netherlands.Vol. 7, No. 2, 232.

[5]. Grimsey, D., \& Lewis, M. (2007). Public private partnerships: The worldwide revolution in infrastructure provision and project finance. Edward Elgar Publishing. 
IRA-International Journal of Management \& Social Sciences

[6]. Grimsey, D., \& Lewis, M. K. (2002). Evaluating the risks of public private partnerships for infrastructure projects. International Journal of Project Management, 20(2), 107-118.

[7]. Ke, Y., Wang, S., \& Chan, A. P. (2010). Risk allocation in public-private partnership infrastructure projects: comparative study. Journal of Infrastructure Systems, 16(4), 343-351.

[8]. Khozaei, F., Ayub, N., Hassan, A. S., \& Khozaei, Z. (2010).The factors predicting students' satisfaction with university hostels, case study, Universiti Sains Malaysia. Asian Culture and History, 2(2), 148.

[9]. Kwak, Y. H., Chih, Y., \& Ibbs, C. W. (2009).Towards a comprehensive understanding of public-private partnerships for infrastructure development. California management review, 51(2), 51-78.

[10]. Nimako, S. G., \& Bondinuba, F. K. (2013).An empirical evaluation of student accommodation quality in higher education.European Journal of Business and Social Sciences, 1(12), 164-177.

[11]. Sawyerr, P. T, \& Yusof, N. A. (2013). Student satisfaction with hostel facilities in Nigerian polytechnics. Journal of Facilities Management, 11(4), 306-322.

[12]. Terwase, I. T., Abdul-Talib, A. N., \& Zengeni, K. T. (2015). Conflict resolution: The truncated zoning arrangement and the Buhari political tsunami in Nigeria. Jurnal Studi Pemerintahan: Journal of Government and Politics, 6(2).

[13]. Terwase, I. T., Abdul-Talib, A. N., \& Zengeni, K. T. (2014). Nigeria, Africa's largest economy: International business perspective. International Journal of Management Sciences, 3(7), 534-543.

[14]. Terwase, I. T., Abdul-Talib, A. N., \& Zengeni, K. T. (2015).The Role of ECOWAS on Economic Governance, Peace and Security Perspectives in West Africa. Mediterranean Journal of Social Sciences, 6(3), 257.

[15]. Terwase, I. T., Abdul-Talib, A. N., Zengeni, K. T., \& Terwase, J. M. (2015). The Psychological Trauma on Boko Haram Victims in Nigeria: Conflict Resolution Perspective. Mediterranean Journal of Social Sciences, 6(6 S4), 519.

[16]. Zhang, X. (2005). Critical success factors for public-private partnerships in infrastructure development. Journal of construction engineering and management, 131(1), 3-14. 